\title{
On the Cretaceous origin of the Order Syracosphaerales and the genus Syracosphaera
}

\author{
Paul R. Bown, Jeremy R. Young \& Jacqueline A. Lees* \\ Department of Earth Sciences, University College London, Gower Street, London WC1E 6BT, UK \\ *Correspondence: j.lees@ucl.ac.uk
}

\begin{abstract}
New scanning electron microscope observations of unadulterated calcareous nannofossil assemblages on lamina surfaces of Cretaceous Tanzania Drilling Project sediments reveal high diversity in the $<3 \mu \mathrm{m}$ size-range and high abundances of small and frangible morphologies. These assemblages prompt comparison to modern assemblages, which show similar high diversity and abundance of very small and fragile taxa, although these assemblages are generally not preserved in the fossil record due to taphonomic filtering. Not only are there broad similarities between the general composition of modern assemblages and those of the Tanzanian lagerstätte, but also our discovery of several new Cretaceous taxa provides evidence for greatly extended fossil lineages of extant orders, with implications for both deep-time biodiversity divergence and survival through the end-Cretaceous mass extinction. Our findings include: new species that are the first-recorded Mesozoic representatives of the extant Syracosphaeraceae and Papposphaeraceae; potentially previously unrecorded diversity in the Mesozoic Calciosoleniaceae, another extant order, represented by extant species that have been described already; and new species and unusually high abundances of the Mesozoic Stephanolithiaceae. We also highlight the extended range of an incertae sedis Cenozoic genus, Ellipsolithus, into at least the Turonian.

Here, we describe seven new miniscule to very small Cretaceous species: Syracosphaera antiqua, S. repagula, Pocillithus macleodii, P. crucifer, Stradnerlithus wendleri, S.? haynesiae and Tortolithus foramen.
\end{abstract}

Keywords: Syracosphaerales, Syracosphaeraceae, Rhabdosphaeraceae, Calciosoleniaceae, Stephanolithiaceae, Cretaceous, Turonian, Tanzania Drilling Project

Received 4 January 2016; accepted 21 June 2016

The second phase of the Tanzania Drilling Project (TDP, 2007-09) primarily targeted Cretaceous stratigraphy and recovered sediments that extend the Kilwa Group microfossil lagerstätte down through a Maastrichtian to Aptian succession. Analysis of the Paleogene Kilwa Group led to the surprising discovery of many extant coccolithophorid taxa that had little or no previous fossil record (e.g. Gladiolithus, Syracosphaera, Algirosphaera, Acanthoica, papposphaerids: Dunkley Jones et al. 2009). Using material from the Cretaceous TDP drilling, we have been looking to see if such taxa ranged into even older time intervals. This is of particular interest because the end-Cretaceous mass extinction event ostensibly saw the loss of the majority of Mesozoic coccolithophores, with most of the modern groups originating in the subsequent Paleocene radiation (e.g. Bown et al. 2004). One of our primary search targets was Syracosphaera and other syracosphaeralids, as this is the most diverse group of extant coccolithophores (Young et al. 2003), with deep (Early Jurassic) divergence times indicated by molecular phylogenies (Medlin et al. 2008; Young et al. 2014), but particularly poor preservation potential due to this group's small and fragile coccolith morphologies, as we explain below. We report here on our discovery of a diversity of miniscule to very small coccoliths from the Turonian of Tanzania, some of which closely resemble Syracosphaera coccoliths. The presence of these coccoliths, and another syracosphaeralid genus, Calciosolenia, confirms the Cretaceous record of this significant group.

The fossil record of calcareous nannoplankton indicates an origination of the group in the Late Triassic, with major diversification events in the Early Jurassic and Early Paleocene (Bown et al. 2004). The Paleocene radiation followed the almost complete elimination of the group at the Cretaceous/Paleogene (K/Pg) mass extinction, and the originations of most modern coccolithophore groups have been recorded from this time, including the Coccolithales, Isochrysidales and Zygodiscales. These particular orders have relatively large and/or robust coccoliths and, consequently, provide long and consistent fossil records that allow evolutionary history reconstructions with strong stratophenetic support. A significant proportion of the modern coccolithophore diversity, however, is less well represented in the fossil record and so the timings of significant evolutionary innovations, such as the first appearance of the Syracosphaeraceae and origination of deep photic-zone taxa (e.g. Gladiolithus), has remained uncertain or unknown. The Tanzanian microfossil lagerstätte provides a unique preservational window, revealing previously unseen diversity of small and fragile coccoliths, and includes records of evolutionary lineages not previously found in the fossil record.

Nannofossils are commonly used as biostratigraphic markers and palaeoceanographic proxies, but despite this widespread use, our knowledge of their taphonomy is still incomplete. It is often assumed that assemblages in seafloor sediments and ancient sedimentary rocks relatively faithfully represent the living populations from which they derive. This assumption has been challenged through the comparison of plankton, sediment-trap and seafloor assemblages (e.g. Roth \& Coulbourn 1982; Andruleit et al. 2004) and through advances in the documentation of living coccolithophore species, many of which produce small, fragile and/or weaklycalcified coccoliths that are not represented in modern seafloor sediments or the Holocene fossil record (Young et al. 2003, 2005; Andruleit et al. 2004). Findings show that, typically, coccoliths that are $<3 \mu \mathrm{m}$ in length are unlikely to enter the fossil record, but larger, fragile coccoliths are equally subject to destruction by mechanical and chemical taphonomic processes acting in the photic zone during export and within the sediment through lithification and diagenesis. This taphonomic bias applies to smaller coccoliths, in particular, because they are more likely to be destroyed during grazing, they 
typically sink more slowly until incorporated in marine snow, and thus they are more susceptible to dissolution in the water column. If they are incorporated into seafloor sediments, they are then more liable to be obliterated by recrystallization, with synchronous dissolution of small crystals and overgrowth of large ones (Wise 1977). Post-sampling, smaller coccoliths are also more likely to be destroyed through preparation techniques, including the making of relatively low-impact smear or settling slides, and they are typically more difficult to observe in the light microscope (LM). Overall, a high degree of assemblage transformation occurs in the water column (e.g. Andruleit et al. 2004) and this is then amplified during post-depositional diagenesis (Wise 1977).

This taphonomic loss is mostly biased towards a small number of modern groups, but these include the most diverse order, the Syracosphaerales, plus a number of less diverse, but functionally significant, groups, such as deep photic-zone, coastal and highlatitude forms (e.g. Gladiolithus, Pleurochrysis, Papposphaera). Typically, one out of four extant orders and seven out of 17 extant families are poorly represented in the fossil record (Young et al. 2005). The poor fossil record of the Syracosphaerales is a particularly significant gap in our understanding of the Cenozoic evolutionary history of coccolithophores and we have not known whether the proliferation of syracosphaeralid coccolithophores, with small, lightly calcified coccoliths, was a relatively recent, Late Neogene phenomenon, or a much longer-lived, but unrecorded, Mesozoic or Early Cenozoic feature of the group.

It has been suggested that one other Mesozoic coccolith group, the small, delicate stephanolithids (Stephanolithiaceae), is a possible Syracosphaerales relative, based on morphological similarities, including multi-bar central-area structures and comparable, but not identical, rim morphology (Perch-Nielsen 1985; Bown \& Young 1997). Coccolithophore molecular phylogenetics suggests that the Syracosphaerales had a deep divergence, possibly rooted in the Early Jurassic diversification (Medlin et al. 2008; Young et al. 2014). In order to address the question of the evolutionary roots of the Syracosphaerales, we need to study exceptionally-preserved assemblages, such as those sampled by the TDP.

\section{Morphology and fossil record of the groups discussed}

\section{Syracosphaerales}

The Order Syracosphaerales comprises the families Calciosoleniaceae, Rhabdosphaeraceae and Syracosphaeraceae. It is the most diverse living coccolithophore group, accounting for c. $25 \%$ of modern species (c. 75 out of 280 species: Young et al. 2003, 2005). These three families are united by possession of similar coccolith structure (Figs 1 and 2): the rim is typically narrow (Figs $1 \mathrm{~b}$ and 2a, d) and shows regular crystallographically vertical/radial (V/R-) unit structure (Figs 1a, c and 2b, e), whilst the central-area is formed from a disjunct cycle of radial laths (Figs 1a, b, g-i and 2a, b, e, f) and often a central structure formed from additional elements (Figs $1 \mathrm{~b}$ and $2 \mathrm{a}, \mathrm{d})$. The radial laths interdigitate with the rim units, and there is typically the same number of these laths as there are rim units, but the radial laths show tangential $c$-axis orientation (i.e. T-units: Young et al. 2003, 2004; Figs 1a, c and 2b, e). The centralarea structures show highly variable morphology, especially in the Rhabdosphaeraceae (e.g. Young et al. 2003; Probert et al. 2007).

\section{Syracosphaeraceae}

The rim structure of Syracosphaera pulchra has been described in detail by Inouye \& Pienaar (1988) and Young et al. (2004), who added crystallographic interpretations based on LM crystal form. The rim is composed of a lower cycle of V-units and an upper cycle of R-units, with a peg-like extension to the protococcolith ring locus, which is near the proximal surface (Fig. 1c and g). The central-area laths interdigitate with the rim units (Fig. 1c), but have tangential $c$-axis orientation. Other species of Syracosphaera, and the genera Ophiaster, Calciopappus and Michaelsarsia, have similar rim-structures, but with variable development of the $\mathrm{V}$ - and R-cycles; typically the R-unit forms most of the rim, as exemplified in Figure 1a by Ophiaster. In Coronosphaera, the structure is similar, but the R-units show strong anticlockwise imbrication.

\section{Rhabdosphaeraceae}

The structure of the Rhabdosphaeraceae has been described many times (e.g. Aubry 1988; Varol 1989; Kleijne 1992) and modern species of Algirosphaera and Rhabdosphaera have been described in particular detail (Probert et al. 2007; van de Locht et al. 2014). The rim consists of an upper/outer cycle with radial sutures and a lower/inner cycle with strongly oblique sutures (Figs $1 \mathrm{~h}$ and 2b, c). A radial lath cycle typically interdigitates with the lower rim cycle units (Fig. $2 b$ and c), although this cycle is absent in Rhabdosphaera, whilst in Blackites there are typically more laths per rim-unit. Observations of Rhabdosphaeraceae coccoliths are not easy in the LM, since the coccoliths are typically small and the rim cycles are closely appressed; however, the larger, upper/outer cycle appears to be formed of $\mathrm{V}$-units and the lower/inner cycle formed of R-units (e.g. Bown 2005, pl. 26, figs 16-24; Fig. 2b).

\section{Calciosoleniaceae}

In the Calciosoleniaceae, the rim is again elevated to give a murolith form, with a well-developed lath cycle in the central-area (Figs $1 \mathrm{i}$ and $2 \mathrm{~d}-\mathrm{f}$ ). These coccoliths have been described in detail by Manton \& Oates (1985) and Malinverno (2004), but the rim structure and crystallography have not been well documented, so we briefly describe it here. In distal view, it is often clear that there are two layers or cycles to the wall (Malinverno 2004; Fig. 2e) and, by comparing specimens in various orientations, it can be seen that the inner cycle extends to the proximal surface and underlies the outer cycle (Figs 1i and 2f). In cross-polarized light, the inner cycle is strongly birefringent (Fig. 2h), with radial crystallographic orientation (R-units), whilst the outer cycle is weakly birefringent (Fig. $2 \mathrm{~g}$ and i), implying subvertical orientation (V-units). The inner cycle is typically better developed in the coccoliths situated toward the ends of the coccosphere and so this part of the coccosphere shows the highest birefringence. This V/R structure is the reverse of that shown by the Syracosphaeraceae, i.e. V-units form the outer/ upper rim cycle in Calciosolenia, but the lower/inner cycle in Syracosphaera (compare Fig. 1g and i). This difference justifies retaining the Calciosoleniaceae as a separate family, at least until molecular genetic data are available. It is also notable that the rim structure of Calciosolenia is very similar to that of the Mesozoic stephanolithids.

\section{Occurrence of Syracosphaerales}

To date, the only members of the Syracosphaerales for which molecular genetic data are available are Syracosphaera pulchra, Coronosphaera mediterranea and Algirosphaera robusta. These cluster together in most analyses, supporting the inference from traditional taxonomy that they are closely related (e.g. Sáez et al. 2004; Young et al. 2005, 2014).

In the fossil record, the Rhabdosphaeraceae can be unambiguously identified by their distinctive rim structure and formation of prominent spines and processes. Similarly, the Calciosoleniaceae are unambiguously identifiable by the combination of rhombicmurolith shape and radial laths, which also are typically offset along the median axis. Identification of the Syracosphaeraceae is more problematic, especially as most species are too small to reliably 


\section{Syracosphaeraceae structure}
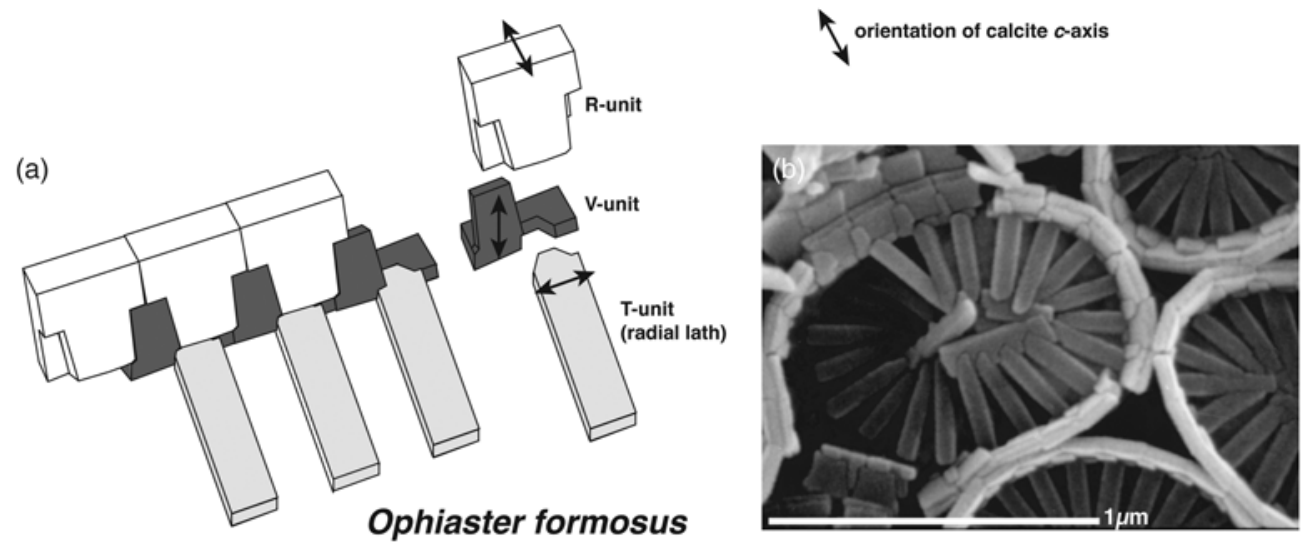

(c)
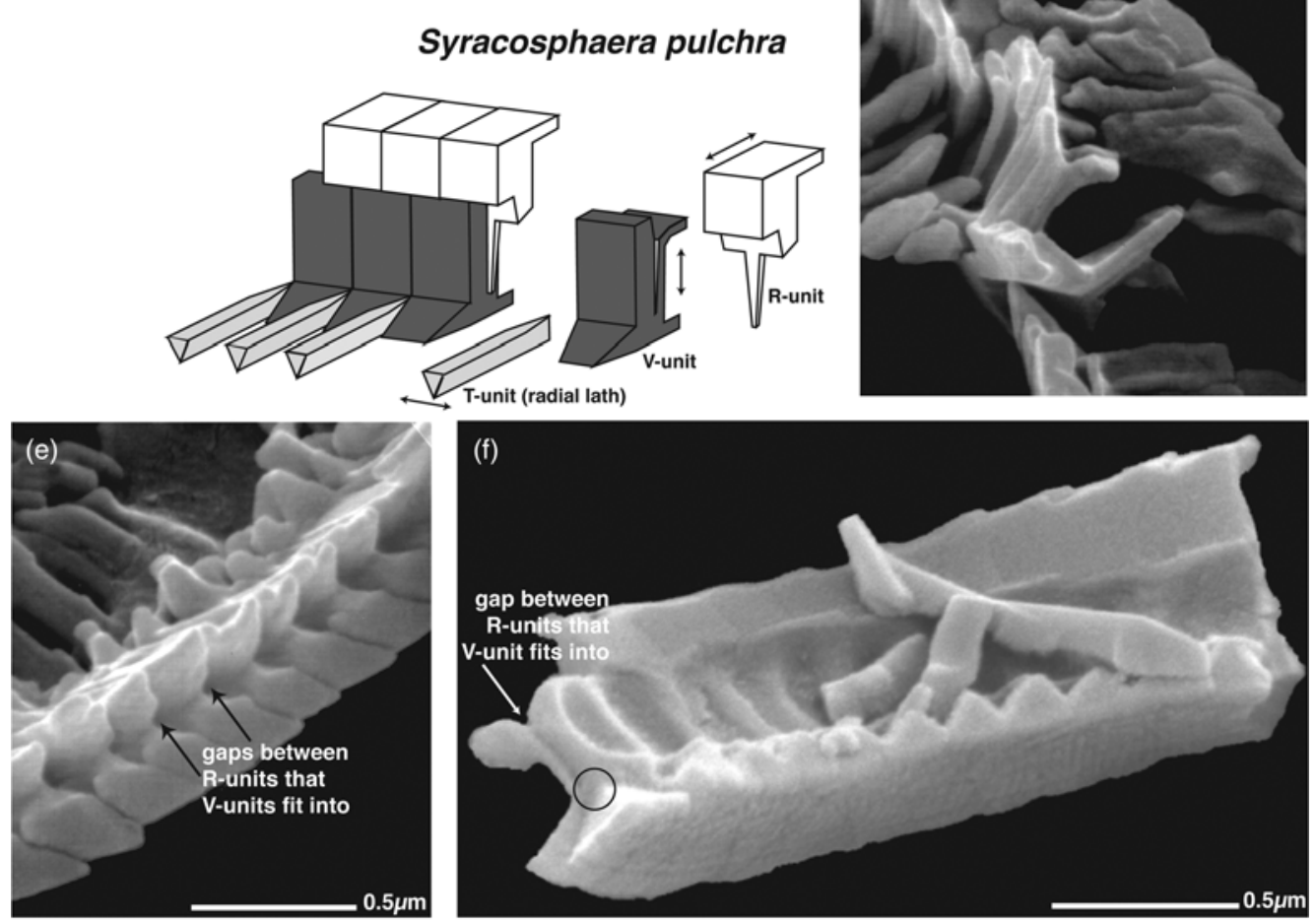

comparative cross-sections of the three Syracosphaerales families

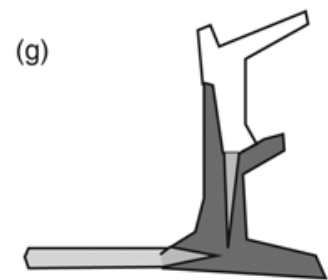

Syracosphaeraceae (S. pulchra) (h)

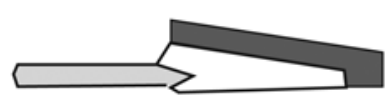

Rhabdosphaeraceae (Acanthoica) (i)

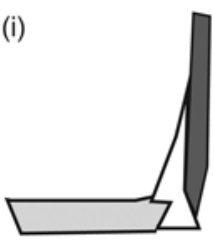

\section{Calciosoleniaceae}

(Calciosolenia)

Fig. 1. Structure of the families of the Order Syracosphaerales - Syracosphaeraceae: (a) interpretative drawing of (b) SEM image of Ophiaster formosus coccoliths; (c) interpretative drawing of (d-f) SEM images of broken portions of Syracosphaera pulchra rim; (g-i) comparison of rim construction in Syracosphaeraceae, Rhabdosphaeraceae and Calciosoleniaceae rims (see Young et al. (2004) for extended explanation).

determine crystallographic orientations from, but we regard the combination of murolith morphology with a central-area formed of disjunct, radial laths, interdigitating with the rim elements, as suggestive of the group.
Overall, the Order Syracosphaerales is poorly represented in the fossil record, although representatives of the Rhabdosphaeraceae are known from the Eocene, and a few Calciosoleniaceae species have been sporadically recorded from the Lower Cretaceous 


\section{Rhabdosphaeraceae and Calciosoleniaceae structure}

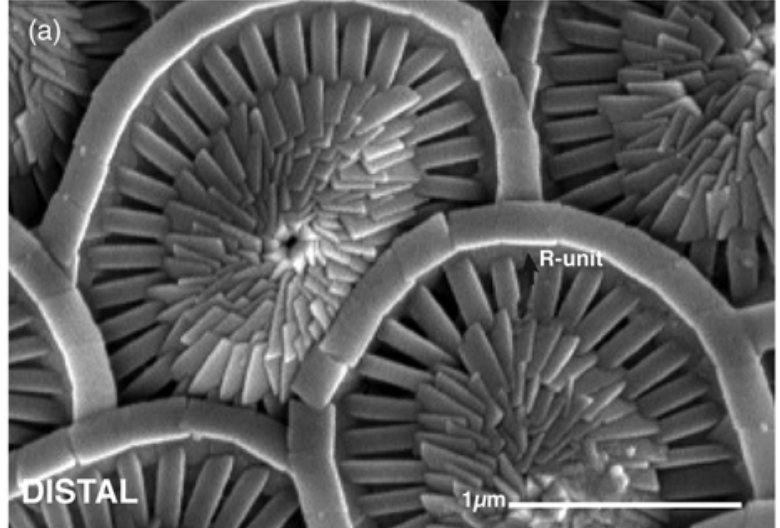

Acanthoica quattrospina
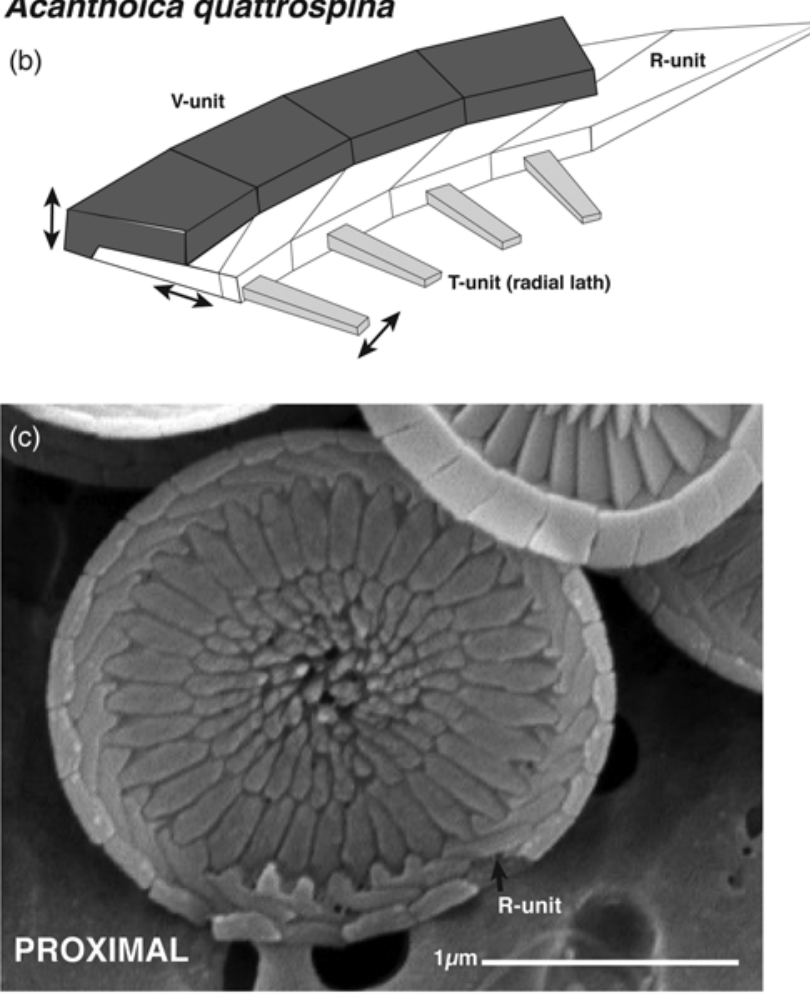

Rhabdosphaeraceae
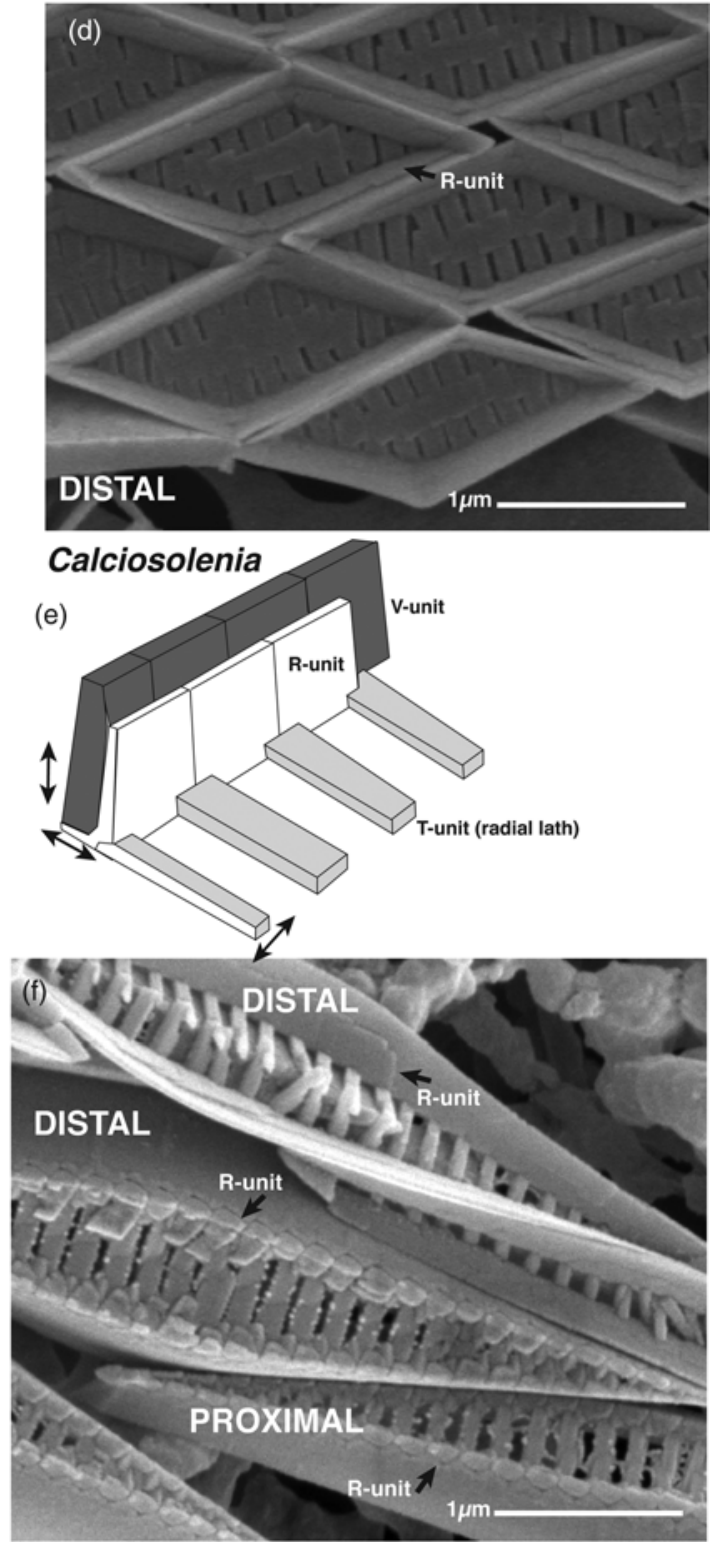

Calciosoleniaceae (g)

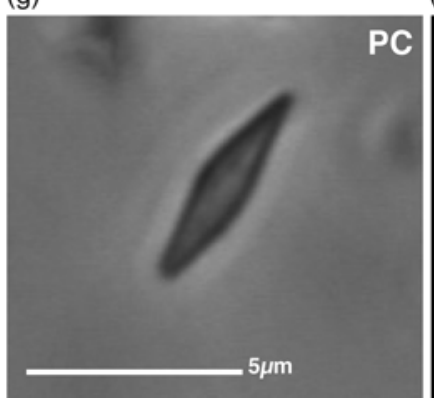

(h)

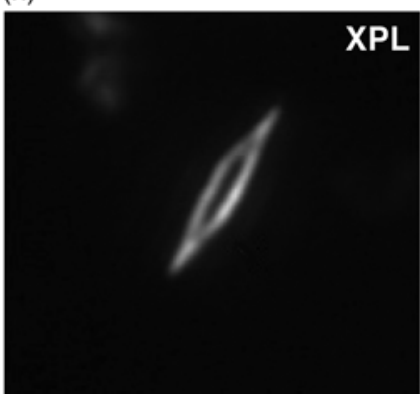

(i)

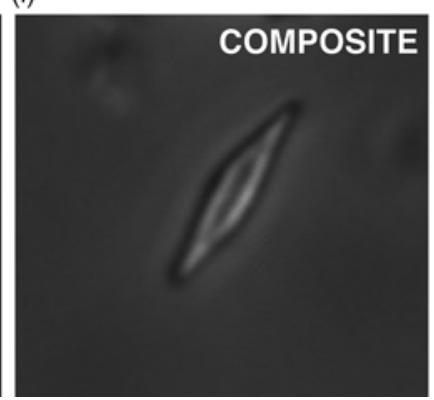

Fig. 2. Structure of the families of the Order Syracosphaerales - Rhabdosphaeraceae and Calciosoleniaceae: (a) distal and (c) proximal SEM images of Acanthoica quattrospina coccoliths, with (b) interpretative drawing; (d and f) SEM images of distal and proximal views of Calciosolenia coccoliths, with (e) interpretative drawing; (g-i) LM images of a single Calciosolenia coccolith: (g) phase-contrast, V-unit dark; (h) crossed-polars, R-unit strongly birefringent; (i) Photoshop composite of (g) superimposed on (h) at 50\% transparency, showing R-unit surrounded by V-unit (compare this with (d) and (e)).

(Valanginian, c. $136 \mathrm{Ma}$ ) to Holocene (Bown 1998b). It has been unclear whether this low palaeodiversity is the result of taphonomic biases (as described above), or actually a reasonable representation of an evolutionary history that has seen a very recent and dramatic diversification, especially in the family Syracosphaeraceae. Although the lack of continuous Neogene sections in Tanzania 
does not allow us to fully address this question, in the Tanzanian Paleogene we have found anomalously high diversities in the Rhabdosphaeraceae ( $>40$ species), including the oldest-yet, unequivocal representatives of the extant genera Acanthoica, Algirosphaera and Rhabdosphaera, and the oldest representatives of Syracosphaeraceae (Syracosphaera and Coronosphaera: e.g. Bown et al. 2009; Dunkley Jones et al. 2009). The presence of six out of 14 living syracosphaeralid genera in the Paleogene indicates that a significant proportion of modern Syracosphaerales diversity was established by at least the Eocene.

Prior to this study, there has been little evidence of a significant Mesozoic fossil record of the Syracosphaerales. This, in part, reflects the significance of the K/Pg boundary mass extinction event (66 Ma), which almost entirely extinguished oceanic coccolithophores and is strongly evidenced by the very different dominant nannofossil taxa seen either side of the boundary (e.g. Bown et al. 2004). Of the living Syracosphaerales, only Calciosolenia (sometimes called by its junior synonym, Scapholithus, in fossil studies) has been unequivocally recognized as having Mesozoic ancestral representatives.

\section{Papposphaeraceae}

This a relatively rare, but diverse, group of extant coccolithophores characterized by producing small coccospheres formed of numerous narrow-rimmed muroliths. The family traditionally included only Papposphaera and Pappomonas, but has been expanded by Andruleit \& Young (2010) to include several other similar genera: Kataspinifera, Picarola, Pseudowigwamma, Vexilarius and Wigwamma. They are best known from Arctic waters, but also occur at lower latitudes, mostly in the middle photic zone (e.g. Cros \& Fortuño 2002). The studied species typically have prominent haptonemata and lack chloroplasts, hence they are inferred to be heterotrophic, rather than autotrophic (Marchant \& Thomsen 1994). The species-level taxonomy of the group is currently being revised (e.g. Thomsen \& Ostergaard 2014) and it appears likely that the group contains at least 30 species. As noted by Andruleit \& Young (2010), five morphological features characterize this group. (1) Rim shape - the coccoliths have simple, narrow murolith rims, i.e. they have a narrow, subvertical outer wall without flanges. In Pappomonas and Papposphaera, the rim has a serrated upper margin, whilst this is smooth in the other species. (2) Rim structure - typically, the majority of the rim is formed of a single cycle of directly abutting elements with subvertical sutures. In addition, a second cycle of elements occurs proximally, with one of these elements interposed between each of the larger elements. (3) Central-area structure-most species possess either an axial cross or an axial cross plus additional elements. (4) Spine structure - the different genera have distinctly different central processes, but in each case, these are hollow structures. (5) Coccolith size - all these genera are characterized by small coccosphere diameter (c. $5 \mu \mathrm{m}$, excluding spines) and miniscule coccoliths (coccolith length typically $1-2 \mu \mathrm{m}$ ).

Prior to the TDP, the group had no known fossil record, but a single species, Pocillithus spinulifer, was described from the Eocene of Tanzania by Dunkley Jones et al. (2009) and its assignment to the Papposphaeraceae was supported by Andruleit \& Young (2010).

\section{Stephanolithiaceae}

This is a well-documented group of Mesozoic coccoliths. They are narrow-rimmed muroliths with vertical elements - V-units form most of the rim, R-units the lower/inner cycle. The central-area contains radial bars, typically formed of multiple elements, sometimes supporting a spine, usually showing low birefringence in LM plan view (e.g. Rhombolithion, Rotelapillus, Stephanolithion, Stradnerlithus geometricus, $S$. fragilis, Truncatoscaphus), but some show moderately birefringent central structures (e.g. Corollithion, Stoverius). The number of (radial) bars varies greatly between taxa, but is typically regarded as constant within species, and there are much fewer bars than rim elements in most taxa. Taxa typically have polygonal or circular outlines. They are conventionally grouped together with the Parhabdolithaceae in the Stephanolithiales (Bown \& Young 1997). The Parhabdolithaceae also have non-imbricate murolith rims, but are typically elliptical, with the central-area spanned by an axial cross or transverse bar.

Although numerous genera and species of Stephanolithiaceae have been described, most of them are infrequently reported, due to their being small, rare, fragile and inconspicuous in the LM. Notable exceptions are, for example, Rotelapillus crenulatus, Corollithion signum and Stephanolithion bigotii, which are relatively larger and more robust, and which are standard components of Mesozoic nannofossil assemblages. Many taxa, however, have only been recorded a very few times and then often from scanning electron microscope (SEM) studies of unusually well-preserved assemblages (e.g. Goy 1981; Lambert 1987).

The family ranges throughout the Mesozoic, from the Early Jurassic to the Late Maastrichtian, but appears to have gone extinct at the $\mathrm{K} / \mathrm{Pg}$ boundary.

\section{Tanzania Drilling Project occurrences}

\section{Material and methods}

TDP Phase II (2007-09) drilled 22 shallow boreholes, 18 of which provide an incomplete, yet extensive, stratigraphic coverage of the Upper Cretaceous (Cenomanian to Maastrichtian), with the others covering short intervals of the Aptian-Albian and MiddleUpper Paleocene. The entire recovered section spans the interval 120-60 Ma. Initial stratigraphic results, based on integrated lithological and micropalaeontological analyses (nannofossils, foraminifera) and stable isotope geochemistry are presented in Jiménez Berrocoso et al. (2010, 2012, 2015). The lithologies are predominantly dark claystones and siltstones, with occasional thin sandstone beds, which have never been deeply buried. Lithofacies and benthic palaeontological analyses indicate deposition in bathyal, outer shelf to upper slope environments at water depths of around 300 - 500 m (Jiménez Berrocoso et al. 2010, 2012, 2015). In the Late Cretaceous, the region was located at around $30^{\circ} \mathrm{S}$ palaeolatitude.

The results presented here are based on observation of broken rock surfaces using an SEM, following the method of Lees et al. (2004; see also Bown et al. 2008 and Lees \& Bown 2016). The rock-surface method is particularly productive in these laminated, hemipelagic sediments, allowing the imaging of in situ nannofossil concentrations on bedding or lamination surfaces, which have remained undisturbed by primary metazoan bioturbation or secondary preparation processes. The method therefore facilitates the observation of exported (in marine snow and faecal pellets) coccolith concentrations, including collapsed coccospheres and small and fragile taxa (Fig. 3).

\section{Results}

Here, we predominantly report on SEM results from the Turonian of TDP Sites 31 and 36, which have been particularly productive for this type of study. At both sites, LM study (Lees 2007, work in progress; Lees \& Bown 2016) has revealed high-diversity assemblages, and the abundant and diverse presence of preservation-sensitive taxa, such as holococcoliths and miniscule to very small heterococcoliths $(<3 \mu \mathrm{m})$. Many samples also conserve frequent, unaltered coccolith concentrations, as observed in the SEM. 

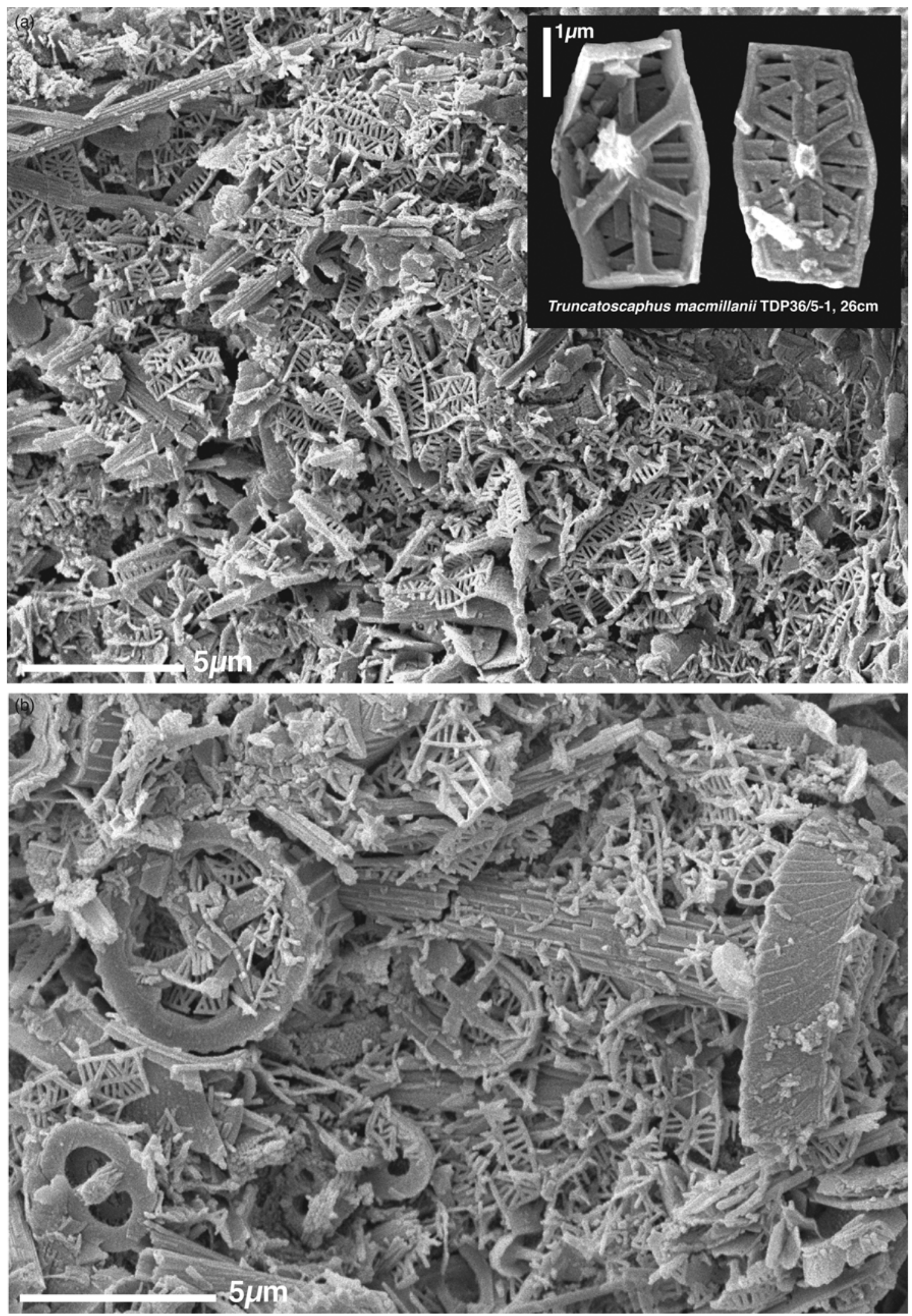

Fig. 3. SEM images of pristine Turonian sediment surfaces (TDP 36/5-1, $26 \mathrm{~cm}$ ) showing (a) concentrations of coccoliths dominated by Truncatoscaphus macmillanii (shown in detail in inset), and (b) view with typical, small to medium-sized, robust Cretaceous coccoliths (Eiffellithus, Rotelapillus, Corollithion, Zeugrhabdotus) along with abundant, frangible Truncatoscaphus and Stradnerlithus.

Nannofossil assemblages in sediments with 'normal' preservation states are typically dominated by larger coccoliths $(5-10 \mu \mathrm{m})$ and tend not to include $<3 \mu \mathrm{m}$ coccoliths or holococcoliths, or if they do, these occur inconsistently, in insignificant numbers and/or are overgrown and consequently made more robust and/or less recognizable (e.g. Young et al. 2005). In Figure 4, we illustrate 24 Cretaceous coccoliths that are $<3 \mu \mathrm{m}$ long, alongside a mediumsized Watznaueria coccolith (c. $8 \mu \mathrm{m}$ long), the latter being a form that typically dominates Jurassic and Cretaceous assemblages. Some of these $<3 \mu \mathrm{m}$ coccoliths are new/recently described taxa 
(Lees 2007; Lees \& Bown 2016; herein) and some are diminutive varieties of known genera (Biscutum, Corollithion, Sollasites). Such coccoliths are seen throughout the Tanzanian succession, and new taxa are discovered frequently, both in the LM and the SEM. Furthermore, a number of these minute and/or fragile taxa are seen frequently to abundantly and/or consistently in the majority of samples, in both the SEM and LM. For example, in the majority of Paleogene samples, Gladiolithus is common, and often dominant.

\section{Calciosoleniaceae}

Calciosolenia is relatively well represented in Tanzanian nannofossil assemblages (seen in the SEM and LM), and is consistently present throughout the Kilwa Group, but in relatively low abundances $(<5 \%)$. Although new species have been described (C. alternans Bown \& Dunkley Jones, 2006; C. huberi Lees, 2007), their diversity is modest and comparable to the modern diversity of just three living species, C. corsellii, C. brasiliensis and C. murrayi, the latter two of which we illustrate here from the Turonian (Fig. 4).

\section{Syracosphaeraceae}

We have found rare Cretaceous coccoliths in the SEM that have morphology that is virtually identical to modern and Paleogene Syracosphaera, and they represent the most convincing Mesozoic records yet of the Syracosphaeraceae (Figs 4-6). The coccoliths are very small $(1.5-2.5 \mu \mathrm{m})$ and fragile, with overall morphology unlike other Mesozoic forms, but with the murolith rim-structure and typical central-area structure (one interdigitating lath-element per rim-element forming the central lath cycle) suggestive of
Cenozoic Syracosphaera. Their diminutive size and fragility suggests that taphonomic bias may well routinely remove any trace of these coccoliths from the deep-time fossil record, but also renders these coccoliths imperceptible, or virtually impossible to identify, using the LM. Although we have yet to find confirmed specimens of these forms in the LM, the SEM specimens are best described as new species of Syracosphaera (see below).

\section{Papposphaeraceae}

Other miniscule to very small coccoliths occur in our Mesozoic samples (Figs 4 and 7). From SEM observation, some of these appear very similar to the species Pocillithus spinulifer, recently described from Eocene TDP samples, and assigned to the Papposphaeraceae (Bown et al. 2008, 2009; Dunkley Jones et al. 2009; Fig. 7b). The new specimens are also muroliths with a high, narrow rim and a tall spine. Two species were observed that differ from each other and $P$. spinulifer in details of outline, central-area, spine cross-section and rim margin. Remarkably, one species, P. macleodii, has a serrated distal margin identical to that of modern Pappomonas and Papposphaera. Clearly, if P. spinulifer is accepted as an Eocene representative of the Papposphaeraceae, then it is reasonable to infer that these new species extend the range of the family into the Late Cretaceous.

\section{Stephanolithiaceae}

Whilst Rotelapillus and Cylindralithus coccoliths are relatively large and robustly constructed, and thus consistently recorded from the Cretaceous in general, and from the TDP LM samples in

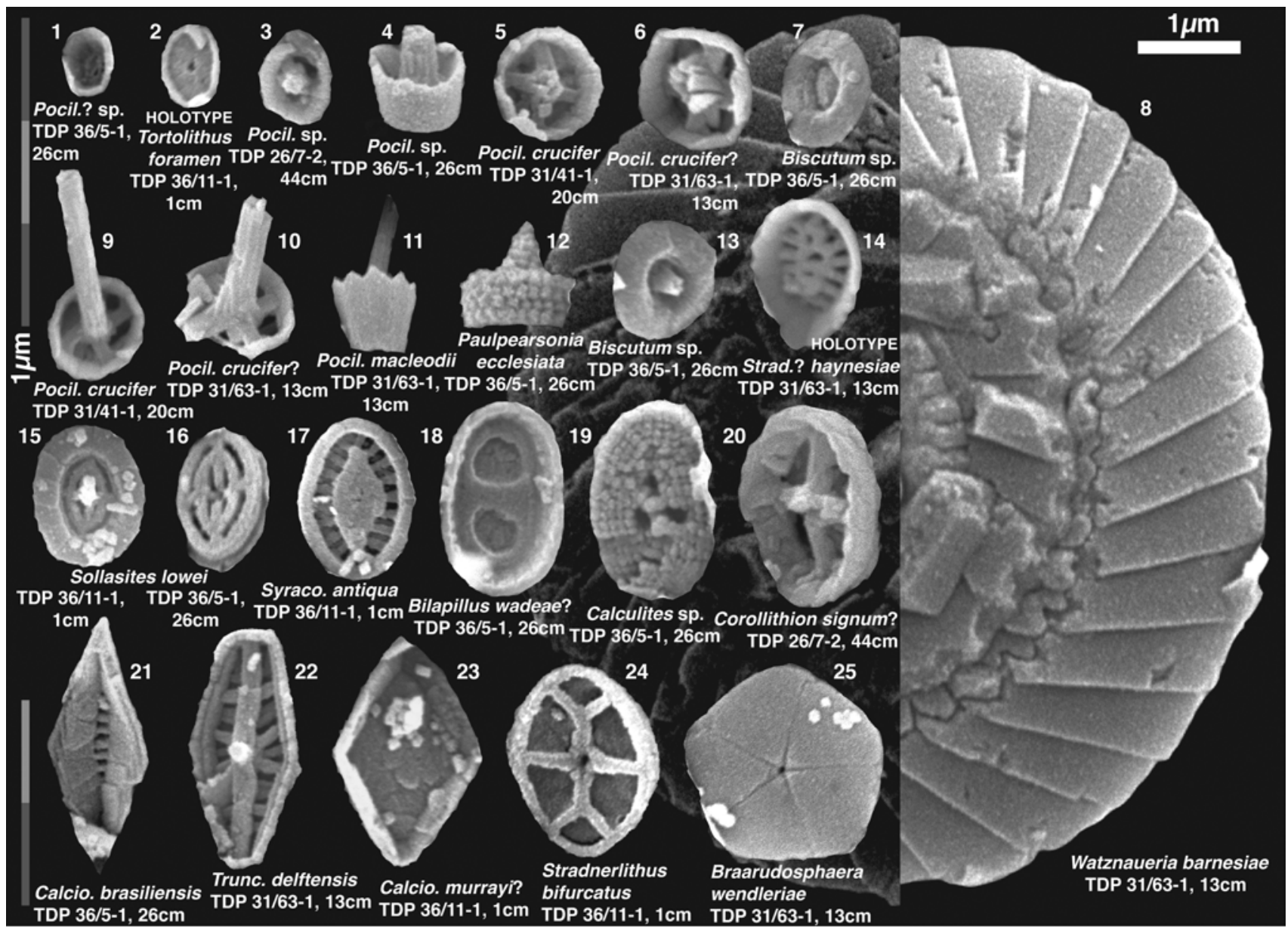

Fig. 4. SEM images of some miniscule to very small (all $<3 \mu \mathrm{m}$ long) Turonian coccoliths (TDP Sites 26,31 and 36 ). The medium-sized Watznaueria barnesiae (c. $8 \mu \mathrm{m}$ long) demonstrates the contrast in size in these assemblages (all at same magnification). 


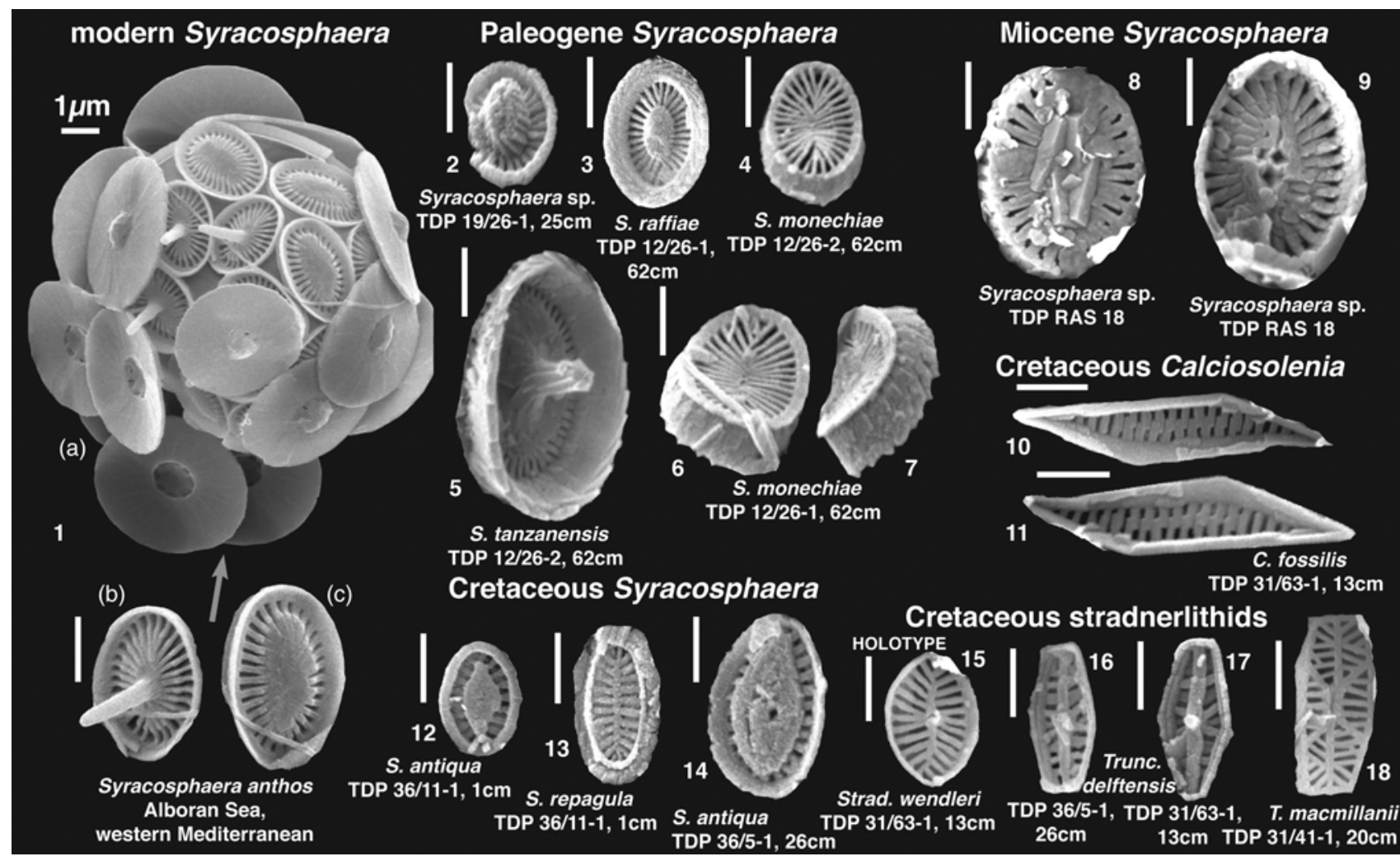

Fig. 5. SEM images of Syracosphaera, Calciosolenia and stradnerlithids (Stradnerlithus and Truncatoscaphus). The Syracosphaeras include modern S. anthos (left) and Tanzanian specimens from the Early Miocene (TDP RAS outcrop sample), Late Eocene (TDP Site 12), Late Paleocene (TDP Site 19) and Turonian (TDP Site 36). Calciosolenia specimens are from the Turonian (TDP Site 31). Stradnerlithid specimens are from the Turonian (TDP Sites 31 and 36 ).

particular (Lees, work in progress), the family Stephanolithiaceae is otherwise poorly represented in the Cretaceous fossil record. In the Tanzanian Turonian SEM samples, however, they are abundant, sometimes dominant, and consistently present (Figs 3-5). They include abundant Truncatoscaphus (usually macmillanii, with subordinate delftensis), and frequent Rhombolithion (usually rhombicum, some rotatum) and Stradnerlithus (bifurcatus, wendleri) specimens. This Truncatoscaphus dominance is surprising, in much the same way as is the dominance of Gladiolithus in the Paleogene samples (Bown et al. 2008, 2009). Both Calciosolenia and Truncatoscaphus are relatively small, but the latter have very low birefringence, and so can be rather inconspicuous in the LM, and this may partly explain their rare documentation. In the Cretaceous TDP LM study, Calciosolenia is a fairly consistent, but rare, assemblage component, whilst Truncatoscaphus, Rhombolithion and Stradnerlithus are only rarely and sporadically recorded (Lees, work in progress). Undoubtedly, the main factor influencing the general record of these stephanolithids is preservation quality, which strongly biases the record of small and frangible coccoliths, as discussed above, but in addition, such taxa seem to be easily lost during even the most gentle preparation of LM slides. Two new species of Stradnerlithus, so far found only in the SEM study, are described below.

In the Turonian samples, we have found Truncatoscaphus and Stradnerlithus in all samples observed in the SEM, with Truncatoscaphus dominating in many of them (Fig. 3); in the LM, taxa such as Calciosolenia, Corollithion, Bilapillus (Figs 3 and 4) and diverse holococcoliths (see Lees 2007) are frequently and fairly consistently present throughout the entire Upper Cretaceous. Truncatoscaphus species have been described from widely-spaced Jurassic and Cretaceous horizons, but they are generally rarely documented and so their consistent and abundant occurrence here is very interesting. These coccoliths are $c .3 \mu \mathrm{m}$ long, but are clearly delicate and frangible (see Fig. 3).

\section{Discussion}

One inference from our observations is that the small, delicate stephanolithids (primarily Truncatoscaphus and Stradnerlithus) may well have been among the most abundant Mesozoic coccoliths, but are essentially un- or under-represented in the deep-time fossil record, due to a pervasive taphonomic filter on fragile coccoliths. This observation is further supported by previous accounts of exceptional Mesozoic preservation ( predominantly in clay-rich, organic-rich and/ or laminated lithologies), which consistently show abundant Truncatoscaphus and/or Stradnerlithus since at least the Early Jurassic (e.g. Early Jurassic - Goy 1981; Late Jurassic - Gallois \& Medd 1979; Bown in Bown \& Cooper 1998a; Lees et al. 2004; Early Cretaceous - Thomsen 1989; mid-Cretaceous-Lambert 1987, 1992). Notably, the Jurassic taxonomic literature includes the description of around 20 species of Stradnerlithus and Truncatoscaphus, a figure that represents around $20 \%$ of the total known Jurassic diversity (c. 85 coccolith species, plus 20 small, delicate stephanolithids: Bown \& Cooper 1998) and this albeit fragmentary record further suggests that they may have been significant assemblage components, in terms of both abundance and diversity.

The Tanzanian microfossil lagerstätte has also revealed the presence of representatives of extant coccolithophore groups that are typically unrepresented in the fossil record, or have rare, sporadic and strongly preservation-mediated records. These TDP records provide new minimum estimates of divergence times for these groups and, in the case of the Syracosphaeraceae and Papposphaeraceae, these are major range extensions (71 and $93 \mathrm{Ma}$, respectively: Fig. 8). Such large range extensions may seem rather surprising for such a well-studied group as the coccolithophorids, with its generally abundant fossil record, but, as discussed above, there are many factors that limit the fidelity of the regular fossil record. Indeed, similar range extensions have recently been proposed for several other coccolithophores: for 


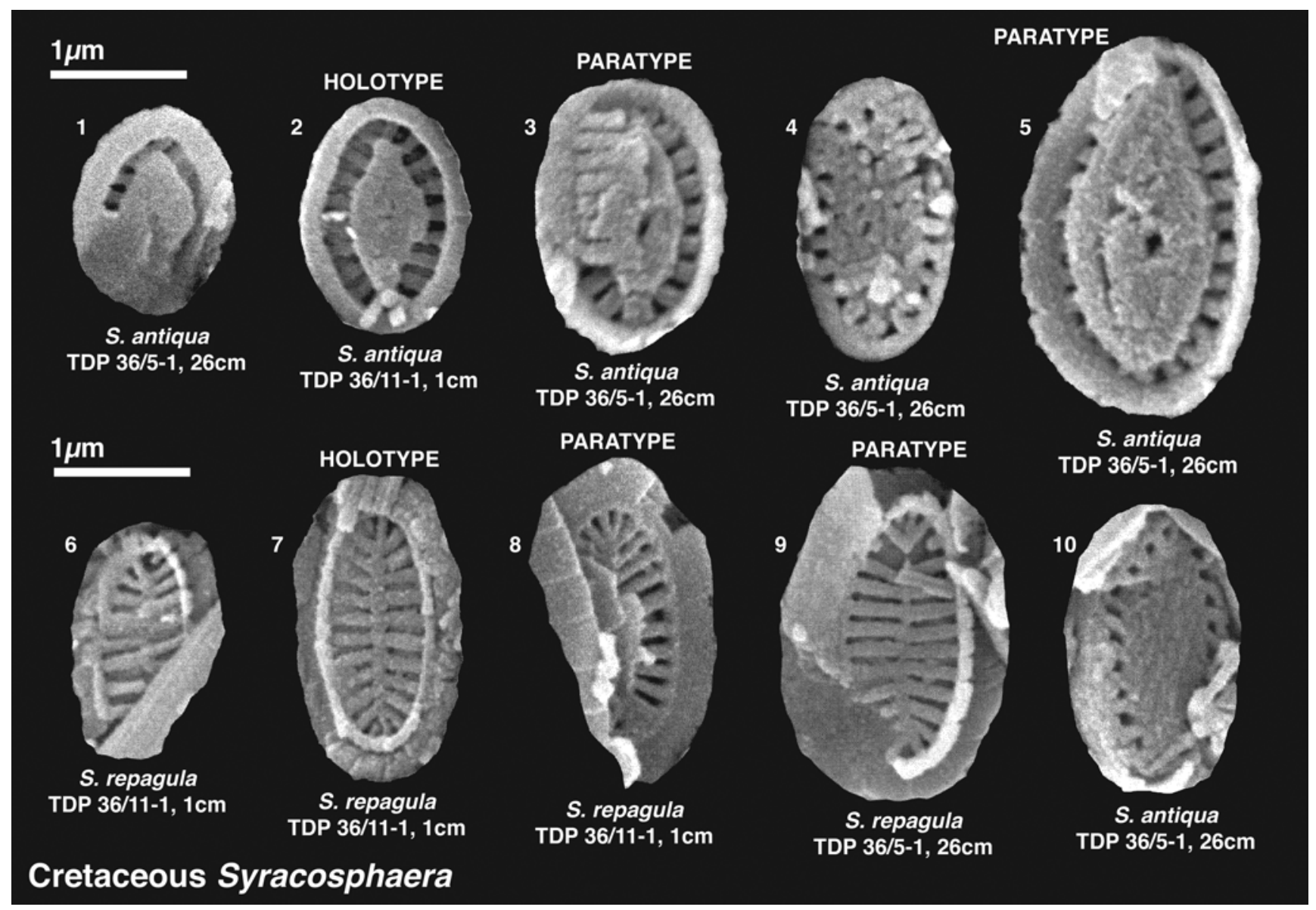

Fig. 6. Cretaceous Syracosphaera.

example, Hagino et al. (2015) described living-fossil evidence that the Watznaueriaceae did not go extinct in the Early Paleogene, but are still extant; Bown et al. (2009) used exceptionally wellpreserved samples from the Paleogene of Tanzania to extend the range of Gladiolithus from the Recent to the Paleocene; and Lees \& Bown (2016) have similarly extended the range of Ellipsolithus, from the Paleocene to the Cenomanian (Fig. 8).

It may be that, of the modern taxa, Syracosphaeraceae is the group that suffers the strongest taphonomic bias because it is represented by especially small and fragile coccoliths, perhaps combined with rare and patchy ecological distributions, which is also a feature of many of the modern Syracosphaera species. The phylogenetic link with the Cretaceous small, delicate stephanolithids is intriguing, but tentative, although based on shared morphological characteristics. We are confident, however, in the evidence provided by the Cretaceous coccoliths identified here as Syracosphaera antiqua and S. repagula, but like the Paleogene records, these Syracosphaera taxa are rare and low in diversity. If the small, delicate stephanolithid group is a deep-time representative of the Syracosphaerales, however, it might suggest that this group has always been a significant component of coccolithophore diversity, and potentially played a significant ecological role, even though it is under-represented in 'normal' nannofossil records.

These new observations bring into focus the likely phylogenetic relationships of classic Mesozoic and Cenozoic groups and, consequently, their classification. Bown (1987) argued that rim structure could be used to classify Jurassic coccoliths into a limited number of phylogenetic groups, including protolith coccoliths, which had non-imbricate murolith rims, classified in the families Parhabdolithaceae and Stephanolithiaceae. This grouping has been followed since then, and was separated out as the Order
Stephanolithiales by Bown \& Young (1997). Based on rim structure alone, the Calciosoleniaceae, and indeed the Papposphaeraceae, could both be included in the Stephanolithiales. Conversely, the Syracosphaerales is essentially defined on the basis of shared central-area structure, i.e. possession of a disjunct cycle of radial laths with tangential $c$-axis orientations. Our observations show that these two groups overlap in geological range and some taxa show characteristics of both groups. Most obviously, this applies to Calciosolenia, but also to some Syracosphaera and Stradnerlithus species (e.g. S. wendleri). So it may be reasonable to predict that the various families discussed here form a single clade, which would suggest that they should all be included in the Order Syracosphaerales. Following on from this, we would predict that molecular genetics will place the Papposphaeraceae within, or sister to, the conventional Syracosphaerales clade. It is also noteworthy that holococcolith stages are widely known within the Syracosphaeraceae, Rhabdosphaeraceae and Papposphaeraceae, so it would be reasonable to infer that the ancestral Stephanolithiaceae, and possibly the Parhabdolithaceae, also produced holococcoliths.

\section{Systematic palaeontology}

Holotype images are curated in the Department of Earth Sciences at UCL.

Order Syracosphaerales Hay, 1977

Remarks: At present, the Order Syracosphaerales comprises three families of living and Cenozoic coccolithophores: the Syracosphaeraceae, Rhabdosphaeraceae and Calciosoleniaceae. These families are characterized by having complex central-areas, disjunct from the rim, and usually with a cycle of radial laths that 

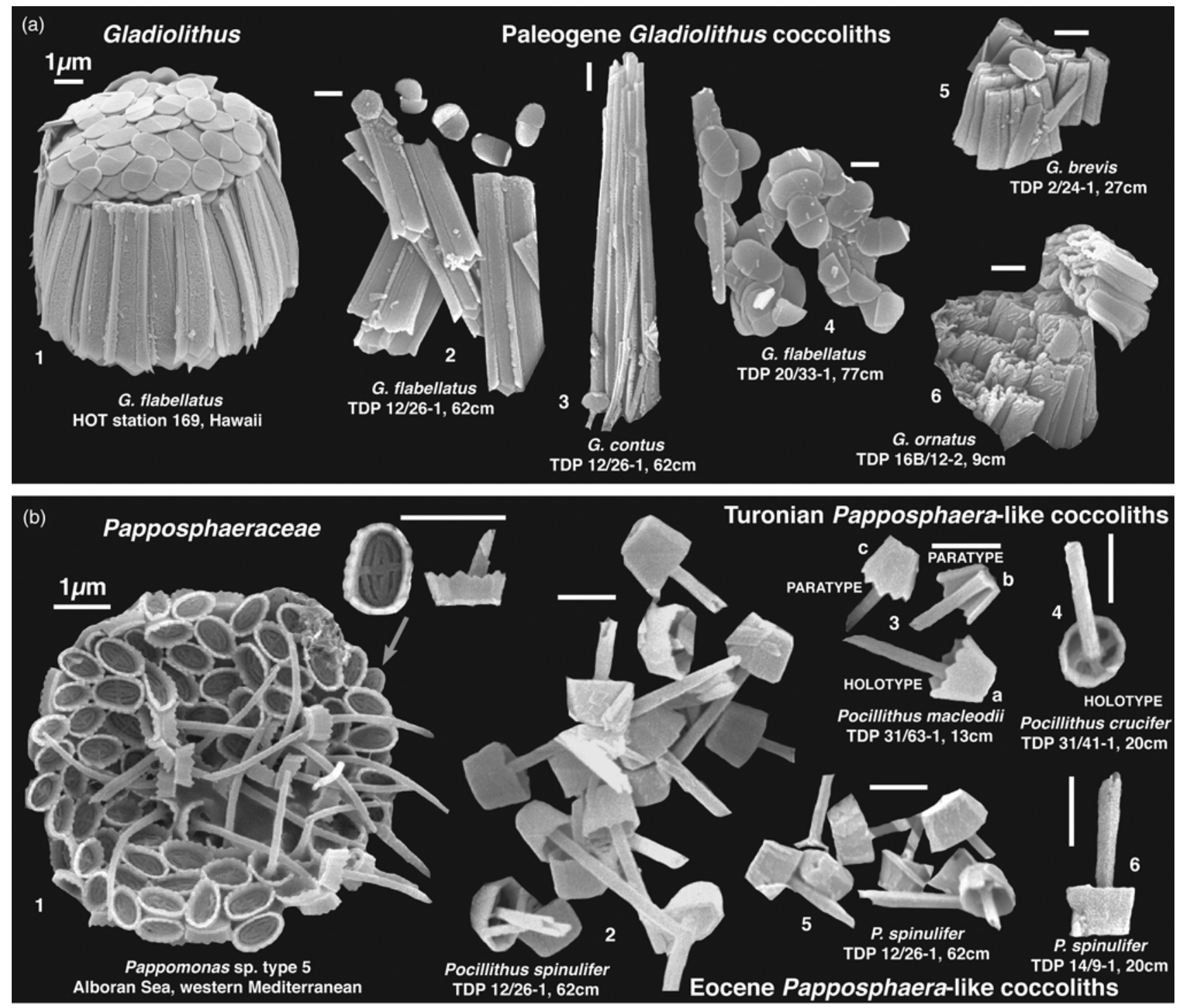

Fig. 7. SEM images of (a) Gladiolithus, showing modern specimens (left) compared to Tanzanian specimens from the Late Eocene (TDP Site 12), Middle Eocene (TDP Sites 2, 20) and Late Paleocene (TDP Site 16); (b) Pappomonas and related forms, showing modern specimens (Pappomonas sp. type 5 of Cros \& Fortuño 2002, left) and Tanzanian specimens (Pocillithus) from the Late Eocene (TDP Site 12), Late Paleocene (TDP Site 14) and Turonian (TDP Site 31).

interdigitate with the rim units, but are discrete from them, and show tangential $c$-axis orientation (Figs 1 and 2; Young et al. 2003, 2004). The Order Syracosphaerales has not generally been used in the Mesozoic; however, the Calciosoleniaceae occur in the Cretaceous, where it shows affinities with the families Stephanolithiaceae and Parhabdolithaceae, which have been classified in the Order Stephanolithiales Bown \& Young, 1997. The Calciosolenia specimens seen in the Mesozoic are identical to those in the Cenozoic, and they have a continuous record across the $\mathrm{K} / \mathrm{Pg}$ boundary, so are clearly the same taxon and need to be classified in the same higher taxonomic group. Therefore, the Syracosphaerales already does occur in the Mesozoic and it appears increasingly likely that it evolved from the Stephanolithiaceae. This leaves the question of whether there is strong enough evidence to transfer the families Stephanolithiaceae and Parhabdolithaceae into the Syracosphaerales, which would make the Order Stephanolithiales redundant. Whilst we think the balance of probabilities is that the Syracosphaerales evolved from the Stephanolithiaceae, we do not have a problem with using paraphyletic taxa, and we are strongly aware both of the value of stability in nomenclature and of the likelihood of new evidence from molecular genetics and/or study of exceptionally-preserved coccoliths from other time intervals. As a general rule, we believe that taxonomic reorganization should be based on conclusive evidence and we feel it is sensible to follow this principle here. So we retain the traditional classification.

Family Syracosphaeraceae Lemmermann, 1908

Genus Syracosphaera Lohmann, 1902

Syracosphaera antiqua sp. nov. Bown, Lees \& Young (Figs. 4:17; 5:12, 5:14; 6:1-5, 6:10)

Derivation of name. From the Latin antiquus, meaning 'coming before', referring to the Cretaceous age of this Syracosphaera species. Diagnosis. SEM - very small, elliptical, murolith coccoliths with narrow rims and wide central-areas spanned by numerous, short, broad, flat, regularly-spaced, radial laths that surround a broad, granular, rhomboidal central plate.

Holotype. Figure 6:2.

Paratypes. Figure 6:3, 6:5.

Type locality. TDP Site 36, west of main road, SW of Lindi, coastal Tanzania.

Type level. TDP36/11-1, $1 \mathrm{~cm}$, Subzone UC6b, Lower Turonian.

Dimensions. Length $=1.7 \mu \mathrm{m}$, width $=1.3 \mu \mathrm{m}$.

Occurrence. TDP Site 36; Lower Turonian; UC6b. 


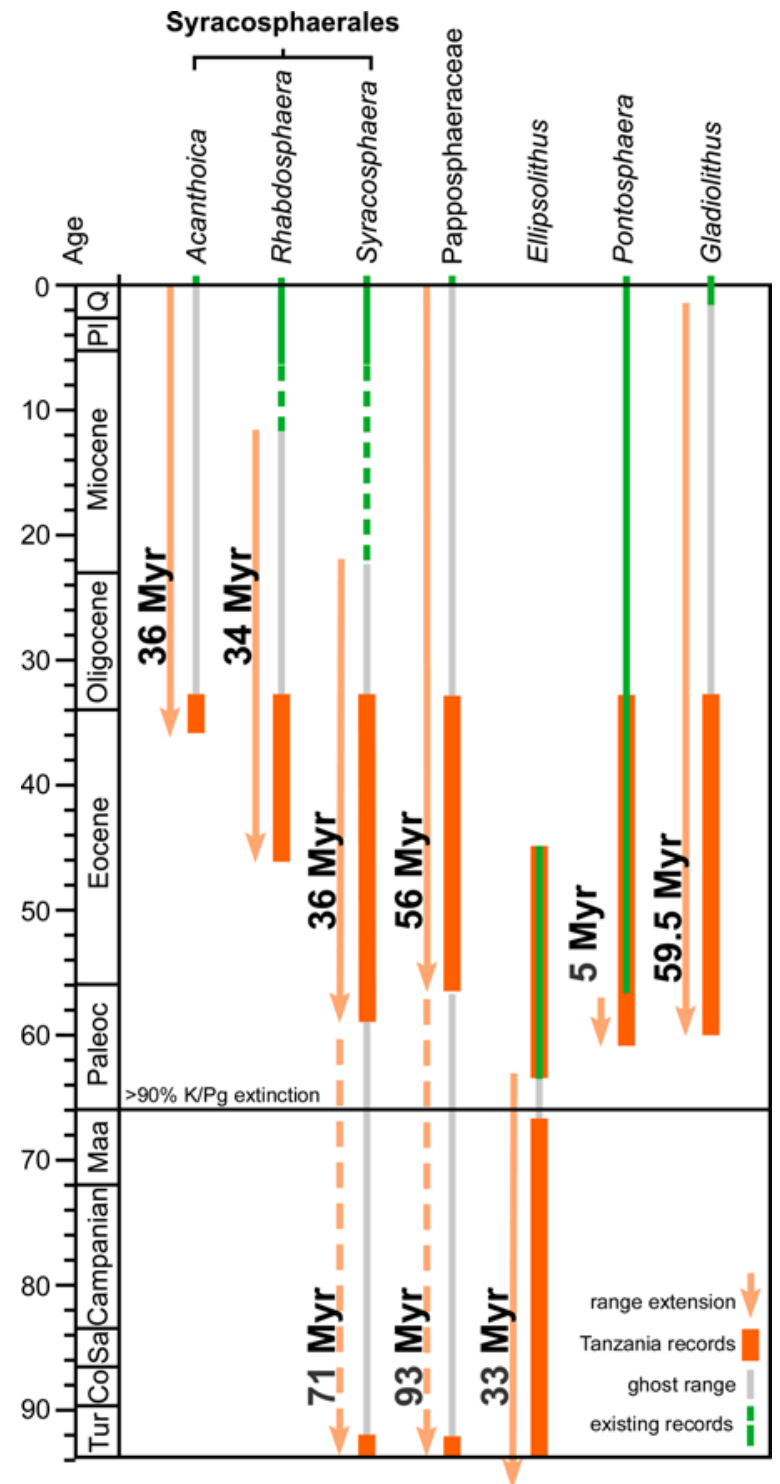

Fig. 8. Significant stratigraphic range extensions for several taxa, revealed by the Tanzanian lagerstätte succession. Range data from Dunkley Jones et al. (2009), Bown (2010, 2016), Lees \& Bown (2016), Lees (work in progress) and herein.

\section{Syracosphaera repagula sp. nov. Bown, Lees \& Young} (Figs 5:13; 6:6-9)

Derivation of name. From the Latin repagula, meaning 'bars', referring to the multiple central-area bars that distinguish this species.

Diagnosis. SEM - very small, elongated, elliptical coccoliths with narrow rims, comprising a broader outer cycle and thin inner cycle (possibly an extended V-unit), and wide, elongated central-areas spanned by numerous short, regularly-spaced, radial laths that meet at a central longitudinal bar.

Holotype. Figure 6:7.

Paratypes. Figure 6:8, 6:9.

Type locality. TDP Site 36, west of main road, SW of Lindi, coastal Tanzania.

Type level. TDP36/11-1, $1 \mathrm{~cm}$, Subzone UC6b, Lower Turonian. Dimensions. Length $=2.2 \mu \mathrm{m}$, width $=1.3 \mu \mathrm{m}$.

Occurrence. TDP Site 36; Lower Turonian; UC6b.

Order Stephanolithiales Bown \& Young, 1997

Family Stephanolithiaceae Black, 1968

Genus Stradnerlithus Black, 1971
Stradnerlithus? haynesiae sp. nov. Lees, Bown \& Young (Fig. 4:14)

Derivation of name. After Dr Shannon Haynes, TDP geochemist. Diagnosis. SEM - very small, elliptical Stradnerlithus-like, murolith coccolith with a relatively high, narrow, flaring murolith rim and an open central-area spanned by a distinctive arrangement of lateral bars that abut against a central, irregular ring of elements that is itself spanned by bars.

Holotype. Figure 4:14.

Type locality. TDP Site 31, WNW of main road, SW of Lindi, coastal Tanzania.

Type level. TDP31/63-1, $13 \mathrm{~cm}$, Subzone UC6b, Lower Turonian. Dimensions. Length $=1.2 \mu \mathrm{m}$, width $=0.9 \mu \mathrm{m}$.

Occurrence: TDP Site 31; Lower Turonian; UC6b.

Remarks. Species of Stradnerlithus more typically have low rims, whereas the rim in this species is relatively moderately high.

Stradnerlithus wendleri sp. nov. Lees, Bown \& Young (Fig. 5:15)

Derivation of name. After Dr Jens Wendler, TDP calcareous dinoflagellate expert and geochemist.

Diagnosis. SEM - a very small, broadly elliptical Stradnerlithus distinguished by having multiple lateral bars (12 each side in this specimen) extending from the rim and meeting at a longitudinal bar that extends for most of the length of the coccolith. Beyond the extent of the longitudinal bar, at the ends of the ellipse axis, the last three lateral bars abut one another, creating an ' $F$ ' pattern. This species bears a short spine.

Holotype. Figure 5:15.

Type locality. TDP Site 31, WNW of main road, SW of Lindi, coastal Tanzania.

Type level. TDP31/63-1, $13 \mathrm{~cm}$, Subzone UC6b, Lower Turonian. Dimensions. Length $=2.1 \mu \mathrm{m}$, width $=1.5 \mu \mathrm{m}$.

Occurrence. TDP Site 31; Lower Turonian; UC6b.

\section{HETEROCOCCOLITHS INCERTAE SEDIS \\ Family Papposphaeraceae Jordan \& Young, 1990}

Genus Pocillithus Dunkley Jones et al., 2009

Pocillithus macleodii sp. nov. Lees, Bown \& Young (Figs 4:11; 7b:3a-c)

Derivation of name. After Prof Ken MacLeod, TDP co-chief and geochemist.

Diagnosis. SEM - miniscule to very small, Pocillithus protolith muroliths with subcircular, high, narrow, flaring, crenulate rims, and central-areas spanned by a proximal plate(?) supporting a tall, narrow, lathy, hollow spine.

Differentiation. Pocillithus crucifer has a central cross supporting the circular-cross-sectioned spine; $P$. spinulifer has a central cross that forms a square spine-base, and the spine is square in cross-section.

Holotype. Figure 7b:3a.

Paratypes. Figure $7 \mathrm{~b}: 3 \mathrm{~b}, \mathrm{c}$.

Type locality. TDP Site 31, WNW of main road, SW of Lindi, coastal Tanzania.

Type level. TDP31/63-1, $13 \mathrm{~cm}$, Subzone UC6b, Lower Turonian. Dimensions. Diameter $($ distal $)=1.0 \mu \mathrm{m}$, coccolith height $=0.8 \mu \mathrm{m}$. Occurrence. TDP Site 31; Lower Turonian; Subzone UC6b.

\section{Pocillithus crucifer sp. nov. Lees, Bown \& Young} (Figs 4:5, 4:6?, 4:9, 4:10?; 7b:4)

Derivation of name. From the Latin crucifer, meaning 'crossbearing', referring to the central cross structure.

Diagnosis. SEM - miniscule to very small Pocillithus protolith muroliths with high, narrow, slightly-flaring rims, and central-areas 
spanned by a proximal plate(?) supporting a right-angled cross that bears a tall, narrow, lathy, hollow spine.

Differentiation. Pocillithus spinulifer has a central cross that forms a square spine-base, and the spine is square in cross-section; P. macleodii has a proximal plate that supports the spine, and no cross.

Holotype. Figure $7 \mathrm{~b}: 4$.

Paratype. Figure 4:5.

Type locality. TDP Site 31, WNW of main road, SW of Lindi, coastal Tanzania.

Type level. TDP31/41-1, $20 \mathrm{~cm}$, Subzone UC6b-7, Lower Turonian.

Dimensions. Diameter $=1.0 \mu \mathrm{m}$.

Occurrence. TDP Site 31; Lower Turonian; Subzone UC6b-UC7.

Remarks. Figure 4:6 and 4:10 may belong to the same species, but have squarish outlines.

\section{MUROLITHS INCERTAE SEDIS}

Genus Tortolithus Crux in Crux et al., 1982

Tortolithus foramen sp. nov. Lees, Bown \& Young (Fig. 4:2)

Derivation of name. From the Latin foramen, meaning 'hole', referring to the central perforation.

Diagnosis. SEM - miniscule, elliptical Tortolithus-like muroliths with low, narrow rims, and central-areas filled by overlapping plates surrounding a central perforation.

Differentiation. No other species of Tortolithus is perforate.

Holotype. Figure 4:2.

Type locality. TDP Site 31, WNW of main road, SW of Lindi, coastal Tanzania.

Type locality. TDP Site 36, west of main road, SW of Lindi, coastal Tanzania.

Type level. TDP36/11-1, $1 \mathrm{~cm}$, Subzone UC6b, Lower Turonian. Dimensions. Length $=0.8 \mu \mathrm{m}$, width $=0.5 \mu \mathrm{m}$.

Occurrence. TDP Site 36; Lower Turonian; Subzone UC6b.

\section{Conclusions}

SEM study of the TDP lagerstätte highlights the fact that taphonomic filtering has a substantial effect on 'normallypreserved' fossil coccolithophorid assemblages, particularly affecting the $<3 \mu \mathrm{m}$ size-range and fragile taxa. It also provides a rare opportunity for us to broadly compare extant with fossil assemblages, as broadly morphologically similar taxa are consistently, and sometimes abundantly, present in TDP sediments. Through such comparison, our observation that the extant Syracosphaerales - the most abundant and diverse living coccolithophorid group - bear a resemblance, in terms of morphology, size, abundance and diversity, to the small, delicate Cretaceous stephanolithids is intriguing. Furthermore, our documentation of Cretaceous Syracosphaera species does support a deep divergence time for the Syracosphaerales, which had previously been hinted at only by the sporadic occurrence of Calciosolenia in the Cretaceous.

In terms of classification, our observations highlight shared morphological features of the Stephanolithiaceae (Mesozoic) and the Calciosoleniaceae and Papposphaeraceae (based on rim structure), which would allow them all to be grouped into the Stephanolithiales. Stradnerlithus and the Calciosoleniaceae share central-area morphologies with the Syracosphaerales, and so could also be classified in that order. Clearly, there is an argument for phylogenetic contiguity of these disparate groups through the $\mathrm{K} / \mathrm{Pg}$ boundary, hitherto obfuscated by the mass extinction event.

Here, through description of several new species, we have documented substantially extended ranges for the Order Syracosphaerales (by up to $71 \mathrm{Myr}$ ) and the family
Papposphaeraceae (by $93 \mathrm{Myr}$ ), adding to recent observations extending the ranges of the incertae sedis genera Ellipsolithus (by $33 \mathrm{Myr}$ ), Pontosphaera (by $5 \mathrm{Myr}$ ) and Gladiolithus (by $59.5 \mathrm{Myr}$ ). This provides evidence for deeper-time evolutionary divergence in all of these groups, and also throws up implications for survival of the $\mathrm{K} / \mathrm{Pg}$ boundary mass extinction and post-extinction recovery.

\section{Acknowledgements and Funding}

The Cretaceous TDP was funded by the NSF (grant to Ken MacLeod, University of Missouri-Columbia and Brian Huber, Smithsonian Institution) and the NERC (grant to JAL and PRB). We thank our reviewers, Emanuela Mattioli and Richard Howe.

\section{Scientific editing by Emanuela Mattioli}

\section{References}

Andruleit, H. \& Young, J.R. 2010. Kataspinifera baumannii: a new genus and species of deep photic coccolithophores resembling the non-calcifying haptophyte Chrysochromulina. Journal of Micropalaeontology, 29 135-147, http://doi.org/10.1144/0262-821X10-006

Andruleit, H., Rogalla, U. \& Stäger, S. 2004. From living communities to fossil assemblages: origin and fate of coccolithophorids in the northern Arabian Sea. Micropaleontology, 50(suppl. 1), 5-21

Aubry, M.-P. 1988. Handbook of Cenozoic calcareous nannoplankton. Book 2. Ortholithae (Catinasters, Ceratoliths, Rhabdoliths). Micropaleontology Press, American Museum of Natural History, New York.

Black, M. 1968. Taxonomic problems in the study of coccoliths. Palaeontology, 11, 793-813.

Black, M. 1971. Coccoliths of the Speeton Clay and Sutterby Marl. Proceedings of the Yorkshire Geological Society, 38, 381-424, http://doi.org/10.1144/ pygs.38.3.381

Bown, P.R. 1987. Taxonomy, biostratigraphy, and evolution of late Triassicearly Jurassic calcareous nannofossils. Special Papers in Palaeontology, $\mathbf{3 8}$ $1-118$.

Bown, P.R. 1998a. Calcareous nannofossils from the upper KimmeridgianVolgian of Gorodische, Russia. In: Bown, P.R. \& Cooper, M.K.E. (eds) Jurassic. In: P.R. Bown (Ed.). Calcareous Nannofossil Biostratigraphy. British Micropalaeontological Society Publications. Chapman \& Hall/Kluwer Academic, London, 48-53.

Bown, P.R. (ed.) 1998b. Calcareous Nannofossil Biostratigraphy. British Micropalaeontological Society Publications. Chapman \& Hall/Kluwer Academic, London.

Bown, P.R. 2005. Palaeogene calcareous nannofossils from the Kilwa and Lindi areas of coastal Tanzania (Tanzania Drilling Project 2003-4). Journal of Nannoplankton Research, 27, 21-95.

Bown, P.R. 2010. Calcareous nannofossils from the Paleocene/Eocene Thermal Maximum interval of southern Tanzania (TDP Site 14). Journal of Nannoplankton Research, 36, 11-38.

Bown, P.R. 2016. Paleocene calcareous nannofossils from Tanzania (TDP Sites 19, 27 and 38). Journal of Nannoplankton Research, 36, 1-32.

Bown, P.R. \& Cooper, M.K.E. 1998. Jurassic. In: Bown, P.R. (ed.) Calcareous Nannofossil Biostratigraphy. British Micropalaeontological Society Publications. Chapman \& Hall/Kluwer Academic, London, 34-85.

Bown, P.R. \& Dunkley Jones, T. 2006. New Paleogene calcareous nannofossil taxa from coastal Tanzania: Tanzania Drilling Project Sites 11 to 14. Journal of Nannoplankton Research, 28, 17-34.

Bown, P.R. \& Young, J.R. 1997. Mesozoic calcareous nannoplankton classification. Journal of Nannoplankton Research, 19, 21-36.

Bown, P.R., Lees, J.A. \& Young, J.R. 2004. Calcareous nannoplankton evolution and diversity through time. In: Thierstein, H.R. \& Young, J.R. (eds) Coccolithophores - From Molecular Processes to Global Impact. Springer, Berlin, 481-508.

Bown, P.R., Dunkley Jones, T. et al. 2008. A Paleogene calcareous microfossil Konservat-Lagerstätte from the Kilwa Group of coastal Tanzania. GSA Bulletin, 120, 3-12.

Bown, P.R., Dunkley Jones, T., Young, J.R. \& Randall, R. 2009. A Palaeogene record of extant lower photic zone calcareous nannoplankton. Palaeontology, 52, 457-469.

Cros, L. \& Fortuño, J.-M. 2002. Atlas of northwestern Mediterranean coccolithophores. Scientia Marina, 66, 1-186.

Crux, J.A., Hamilton, G.B., Lord, A.R. \& Taylor, R.J. 1982. Tortolithus gen. nov. Crux and new combinations of Mesozoic calcareous nannofossils from England. INA Newsletter, 4, 98-101.

Dunkley Jones, T., Bown, P.R. \& Pearson, P.N. 2009. Exceptionally well preserved upper Eocene to lower Oligocene calcareous nannofossils (Prymnesiophycidae) from the Pande Formation (Kilwa Group), Tanzania Journal of Systematic Palaeontology, 7, 359-411.

Gallois, R.W. \& Medd, A.W. 1979. Coccolith-rich marker bands in the English Kimmeridge Clay. Geological Magazine, 116, 247-334.

Goy, G. 1981. Nannofossiles calcaires des schistes carton (Toarcien inférieur) du Bassin de Paris. Documents de la RCP 459, éditions BRGM, 1-86. 
Hagino, K., Young, J.R., Bown, P.R., Godrijan, J., Kulhanek, D.K., Kogane, K \& Horiguchi, T. 2015. Re-discovery of a 'living fossil' coccolithophore from the coastal waters of Japan and Croatia. Marine Micropaleontology, 116, 28-37.

Hay, W.W. 1977. Calcareous nannofossils. In: Ramsay, A.T.S. (ed.) Oceanic Micropalaeontology 2. Academic Press, London, 1055-1200.

Inouye, I. \& Pienaar, R.N. 1988. Light and electron microscope observations of the type species of Syracosphaera, S. pulchra (Prymnesiophyceae). British Phycological Journal, 23, 205-217.

Jiménez Berrocoso, Á., MacLeod, K.G. et al. 2010. Lithostratigraphy, biostratigraphy and chemostratigraphy of the Upper Cretaceous sediments from southern Tanzania: Tanzania Drilling Project Sites 21-26. Journal of African Earth Sciences, 57, 47-69.

Jiménez Berrocoso, Á., Huber, B.T. et al. 2012. Lithostratigraphy, biostratigraphy and chemostratigraphy of Upper Cretaceous and Paleogene sediments from southern Tanzania: Tanzania Drilling Project Sites 27 to 35. Journal of African Earth Sciences, 70, 36-57.

Jiménez Berrocoso, Á., Huber, B.T. et al. 2015. The Lindi Formation (upper Albian-Coniacian) and Tanzania Drilling Project Sites 36-40 (Lower Cretaceous to Paleogene): lithostratigraphy, biostratigraphy and chemostratigraphy. Journal of African Earth Sciences, 101, 282-308.

Jordan, R.W. \& Young, J.R. 1990. Proposed changes to the classification system of living coccolithophorids. INA Newsletter, 12, 15-18.

Kleijne, A. 1992. Extant Rhabdosphaeraceae (coccolithophorids, class Prymnesiophyceae) from the Indian Ocean, Red Sea, Mediterranean Sea and North Atlantic Ocean. Scripta Geologica, 100, 1-63.

Lambert, B. 1987. Nannofossiles calcaires de l'Albien supérieur et du Vraconnien du Cameroun méridional. Cahiers de Micropaléontologie, 2, 33-60.

Lambert, B. 1992. Nannofossiles calcaires de l'Albien supérieur et du Vraconnien du Cameroun méridional (Deuxième Partie). Cahiers de Micropaléontologie, 8, 183-267.

Lees, J.A. 2007. New and rarely reported calcareous nannofossils from the Late Cretaceous of coastal Tanzania: outcrop samples and Tanzania Drilling Project Sites 5, 9 and 15. Journal of Nannoplankton Research, 29, 39-65.

Lees, J.A. \& Bown, P.R. 2016. New and intriguing calcareous nannofossils from the Turonian (Upper Cretaceous) of Tanzania. Journal of Nannoplankton Research, 36, 83-95.

Lees, J.A., Bown, P.R. \& Young, J.R. 2004. Evidence for annual records of phytoplankton productivity in the Kimmeridge Clay Formation coccolith stone bands (Upper Jurassic, Dorset, UK). Marine Micropaleontology, 52, 29-49.

Lemmermann, E. 1908. Flagellatae, Chlorophyceae, Coccosphaerales und Silicoflagellatae. In: Brandt, K. \& Apstein, C. (eds) Nordisches Plankton Botanischer Teil. Lipsius \& Tischer, Kiel.

Lohmann, H. 1902. Die Coccolithophoridae, eine Monographie der Coccolithen bildenden Flagellaten, zugleich ein Beitrat zur Kenntnis des Mittelmeerauftriebs. Archiv für Protistenkunde, 1, 89-165.

Malinverno, E. 2004. Morphological variability within the genus Calciosolenia (coccolithophorids) from the eastern Mediterranean Sea. Micropaleontology, 50(suppl. 1), 81-91.
Manton, I. \& Oates, K. 1985. Calciosoleniaceae (coccolithophorids) from the Galapagos Islands: unmineralized components and coccolith morphology in Anoplosolenia and Calciosolenia, with comparative analysis of equivalents in the unmineralized genus Navisolenia (Haptophyceae=Prymnesiophyceae) Philosophical Transactions of the Royal Society of London (B), 309, 461-477.

Marchant, H.J. \& Thomsen, H.A. 1994. Haptophytes in polar waters. In: Green, J.C. \& Leadbeater, B.S.C. (eds) The Haptophyte Algae. The Systematics Association Special Volume. Clarendon Press, Oxford, 209-228.

Medlin, L.K., Sáez, A.G. \& Young, J.R. 2008. A molecular clock for coccolithophores and implications for selectivity of phytoplankton extinctions across the K/T boundary. Marine Micropaleontology, 67, 69-86.

Perch-Nielsen, K. 1985. Cenozoic calcareous nannofossils. In: Bolli, H.M., Saunders, J.B. \& Perch-Nielsen, K. (eds) Plankton Stratigraphy. Cambridge University Press, Cambridge, 427-554.

Probert, I., Fresnel, J., Billard, C., Geisen, M. \& Young, J.R. 2007. Light and electron microscope observations of Algirosphaera robusta (Prymnesiophyceae). Journal of Phycology, 43, 319-332.

Roth, P.H. \& Coulbourn, W.T. 1982. Floral and solution patterns of coccoliths in surface sediments of the north Pacific. Marine Micropaleontology, 7, 1-52.

Sáez, A.G., Probert, I., Young, J.R., Edvardsen, B., Wenche, E. \& Medlin, L.K. 2004. A review of the phylogeny of the Haptophyta. In: Thierstein, H.R. \& Young, J.R. (eds) Coccolithophores - From Molecular Processes to Global Impact. Springer, Berlin, 251-270.

Thomsen, E. 1989. Seasonal variation in boreal Early Cretaceous calcareous nannofossils. Marine Micropaleontology, 15, 123-152.

Thomsen, E. \& Ostergaard, J.B. 2014. Coccolithophorids in polar waters: Pappomonas spp. revisited. Acta Protozoologica, 53, 235-256.

van de Locht, R., Slater, T.J.A., Verch, A., Young, J.R., Haigh, S.J. \& Kröger, R. 2014. Ultrastructure and crystallography of nanoscale calcite building blocks in Rhabdosphaera clavigera coccolith spines. Crystal Growth and Design, 14, 1710-1718.

Varol, O. 1989. Eocene calcareous nannofossils from Sile (northwest Turkey) Revista Española de Micropaleontología, 21, 273-320.

Wise, S.W. 1977. Chalk formation: early diagenesis. In: Anderson, N.R. \& Malahoff, A. (eds) The Fate of Fossil Fuel $\mathrm{CO}_{2}$ in the Oceans. Plenum, New York, 717-739.

Young, J.R., Geisen, M., Cros, L., Kleijne, A., Sprengel, C., Probert, I. \& Ostergaard, J. 2003. A guide to extant coccolithophore taxonomy. Journal of Nannoplankton Research, Special Issue, 1.

Young, J.R., Henriksen, K. \& Probert, I. 2004. Structure and morphogenesis of the coccoliths of the CODENET species. In: Thierstein, H R \& Young, J.R. (eds) Coccolithophores - From Molecular Processes to Global Impact. Springer, Berlin, 191-216

Young, J.R., Geisen, M. \& Probert, I. 2005. A review of selected aspects of coccolithophore biology with implications for paleodiversity estimates. Micropaleontology, 51, 267-288.

Young, J.R., Liu, H., Probert, I., Aris-Brosou, S. \& de Vargas, C. 2014 Morphospecies v. phylospecies concepts for evaluating phytoplankton diversity: The case of the coccolithophores. Cryptogamie, Algologie, 35, 353-377. 